JAMP: Jurnal Adminitrasi dan Manajemen Pendidikan

Volume 2 Nomor 4 Desember 2019, Hal : 172-180

Tersedia Online di http://journal2.um.ac.id/index.php/jamp/

ISSN 2615-8574 (online)

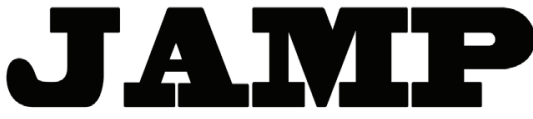

JURNAL ADMINISTRASI DAN MANAJEMEN PENDIDIKAN

\title{
ANALISIS PENGEMBANGAN KARIR PERSONEL SATUAN PENGAMANAN UNIVERSITAS NEGERI
}

\author{
Muhammad Habib Mustofa \\ Agus Timan \\ Wildan Zulkarnain
}

\author{
Universitas Negeri Malang, Jalan Semarang 5 Malang 65145 \\ Email: habibmustofa126@gmail.com
}

\begin{abstract}
The study aims to describe (1) how long the duration of security works; (2) the scurities honorarium; (3) the duties of the security; (4) the scurity career development criteria; (5) career position that were once held at state universities in Malang city. The analysis method of this study is quantitative approach with a descriptive stastical research. The result of this study show that duration of security work is 8 hours with 3 shift per day. The securities salary is 1,5 million to 2 million per month. There are 19 types of duties carried out by security and 2 types of duties including the main duty and functions of security. There are 5 security career developments, namely rating and evaluation, training, work performance, loyality and dedication, and educational background. There are 8 career positions that have been occupied by security.
\end{abstract}

Keywords: career development, duration work, salary, duty, security

\begin{abstract}
Abstrak: penelitian ini bertujuan untuk mendeskripsikan (1) berapa lama durasi kerja Satpam; (2) honorarium Satpam; (3) tugas-tugas Satpam; (4) kriteria pengembangan karir Satpam; (5) karir jabatan yang pernah diduduki Satpam universitas negeri di Kota Malang. Penelitian ini menggunakan pendekatan kuantitatif dengan rancangan penelitian statistik deskriptif. Hasil penelitian menunjukkan bahwa, durasi kerja Satpam adalah 8 jam kerja dengan 3 shift per hari. Perolehan gaji Satpam, yaitu 1,5 juta sampai dengan 2 juta per bulannya. Terdapat 19 jenis tugas yang dilakukan oleh Satpam, dan 2 jenis tugas di antaranya di luar tugas pokok, dan fungsi Satpam. Terdapat 5 pengembangan karir Satpam, yaitu penilaian dan evaluasi, pelatihan, prestasi kerja, kesetiaan atau pengabdian, dan latar belakang pendidikan. Serta terdapat 8 karir jabatan yang pernah diduduki oleh Satpam.
\end{abstract}

Kata Kunci: pengembangan karir, durasi kerja, gaji, tugas, Satpam

Menentukan pilihan karir yang sesuai dengan kepribadian yang dimiliki individu merupakan hal yang penting untuk diperhatikan. Menurut Siagian (2006: 203) berpendapat, bahwa pengembangan karir adalah "setiap karyawan harus mempunyai gambaran yang jelas tentang anak tangga tertinggi apa yang bisa dicapainya selama dia menampilkan kinerja yang memuaskan". Satpam universitas merupakan warga dan pegawai dalam universitas yang sudah menjadi tanggung jawab pihak universitas untuk menyejahterakan dan memberikan apresiasi terhadap pekerjaannya. Satpam merupakan seseorang yang berada di lingkungan universitas, akan tetapi tidak terlibat langsung dalam proses kegiatan belajar mengajar. Citra Satpam di tengah-tengah masyarakat sebagai pekerjaan rendahan, tidak memiliki jenjang karir, atau bahkan ada yang menyebutnya pengangguran yang diberikan solusi menjadi petugas keamanan. Tidak dapat dipungkiri jika masih ada orang-orang maupun perusahaan yang merekrut 
Satpam secara sembarangan. Akan tetapi hal tersebut bisa dihindari apabila Satpam bisa merencanakan dan mengelola karirnya dengan baik.

Satpam merupakan satu-satunya tenaga kependidikan yang 24 jam berada di universitas. Jam kerja Satpam dibagi menjadi tiga shift dalam sehari. Shift pagi berkisar antara jam 06.30-14.30, shift siang yang berkisar antara jam 14.30 - 22.30, dan shift malam yang berkisar antara $22.30-06.30$. Dari pembagian jam kerja tersebut masih banyak Satpam yang mengeluh, karena kebagian jam kerja malam. Tidak hanya itu, setiap kali ada acara penting di universitas dan kedatangan tamu penting, Satpam harus bekerja lembur bahkan satu sampai dua hari tidak pulang. Jika seorang Satpam telah melaksanakan tugas dan kewajibannya dengan baik, maka sudah menjadi tanggung jawab pihak universitas untuk memberikan balikan atas pekerjaannya.

Kompetensi yang harus dimiliki seorang Satpam adalah menguasai kondisi keamanan universitas, menguasai teknik pengamanan universitas, menerapkan prosedur operasi standar pengamanan universitas. Selain dituntut untuk menguasai kompetensi tersebut Satpam juga bertugas sebagai juru parkir, menjaga gerbang universitas, menjaga gedung rektorat, serta mengontrol setiap sudut-sudut universitas. Belum lagi apabila ada kasus pencurian sepeda motor, kebakaran, dan demo mahasiswa. Satpam juga dituntut untuk disiplin, murah senyum, ramah, sopan, dan santun kepada setiap orang. Perencanaan karir diperlukan agar Satpam mempunyai gambaran yang jelas tentang apa yang nantinya dicapai dengan menampilkan atau melaksanakan tugas dan tanggung jawabnya dengan baik. Setiap pegawai memiliki hak untuk memperoleh pengembangan karir begitu juga dengan Satpam.

Satpam merupakan salah satu dari tenaga kependidikan di lingkup sekolah dan universitas negeri maupun swasta yang harus diperhatikan jika dilihat dari tugas dan tanggung jawab, gaji serta jam kerjanya. Bentuk perhatian yang dapat dilakukan di antaranya dengan memperhatikan karir dan pengembangan karir Satpam, sehingga mereka mampu bekerja secara profesional. Berdasarkan latar belakang yang telah diuraikan di atas, peneliti tertarik untuk mengetahui secara lebih jelas tentang analisis pengembangan karir Satpam. Oleh karena itu, judul yang diangkat dalam penelitian ini adalah tentang ‘Analisis Pengembangan Karir Personel Satpam Universitas Negeri di Kota Malang'.

\section{METODE}

Penelitian ini menggunakan metode penelitian pendekatan kuantitatif dengan rancangan penelitian statistik deskriptif. Variabel penelitian ini yaitu pengembangan karir. Lokasi penelitian ini bertempat di universitas negeri di Kota Malang, yaitu Universitas Brawijaya, Universitas Islam Negeri Malang, dan Universitas Negeri Malang. Populasi penelitian ini berjumlah 351 orang Satpam. Selanjutnya untuk memperoleh jumlah sampel yaitu menggunakan formula Slovin, sehingga mendapatkan jumlah sampel sebanyak 187 orang Satpam.

Teknik pengambilan dan penentuan sampel yang digunakan pada masing-masing universitas negeri menggunakan proportional random sampling. Alasan peneliti menggunakan teknik proportional random sampling dikarenakan masing-masing sampel dari populasi dapat diambil secara berimbang sesuai dengan jumlah populasi yang ada, dengan melakukan pengambilan anggota dari masing-masing populasi dilakukan secara acak tanpa memperhatikan status. Seperti mengambil sampel dengan cara pengundian.

Teknik pengumpulan data yang digunakan pada penelitian ini yaitu menggunakan angket atau kuesioner. Angket atau kuesioner yang digunakan pada penelitian ini yaitu angket tertutup dan angket terbuka. Peneliti menggunakan angket tertutup dan terbuka, karena ingin memberikan kesempatan yang luas untuk responden dalam menjawab pertanyaan dan agar peneliti juga dapat membawa responden untuk menjawab sesuai dengan tujuan penelitian. Pada angket penelitian terdapat 37 item pernyataan tertutup dan 2 item pertanyaan terbuka, yaitu tugas lain-lain Satpam dan jabatan yang pernah diduduki oleh Satpam. Angket penelitian sebelum digunakan harus melalui dua analisis uji instrumen, yaitu uji validitas dan uji reliabilitas instrumen. Data yang diperoleh yaitu langsung dari penyebaran angket atau kuesioner kepada Satpam universitas negeri di Kota Malang. 
Adapun teknis analisis data yang digunakan pada penelitian ini adalah analisis data deskriptif. Menurut Sugiyono (2011: 147), metode analisis deskriptif adalah "statistik yang digunakan untuk menganalisis data dengan cara mendeskripsikan atau menggambarkan data yang telah terkumpul sebagaimana adanya tanpa bermaksud membuat kesimpulan yang berlaku untuk umum atau generalisasi". Data yang dibutuhkan adalah data yang sesuai dengan masalah yang ada dan sesuai dengan tujuan penelitian, sehingga data tersebut akan dikumpulkan, diolah, dianalisis, dan diproses lebih lanjut sesuai dengan teori yang telah dipelajari, sehingga dari data tersebut dapat ditarik kesimpulan agar dapat diperoleh hasil analisis.

\section{HASIL}

\section{Durasi Kerja Satpam}

Durasi kerja Satpam sudah ditentukan oleh universitas dan sudah dijelaskan sebelum atau pada saat Satpam diterima bekerja. Durasi kerja Satpam di setiap universitas sama akan tetapi pada pelaksanaannya yang berbeda.

Tabel 1 Durasi Kerja Satpam Per Hari

\begin{tabular}{ccc}
\hline Kategori & Frekuensi & Persentase \\
\hline $1-8$ jam & 187 & $100 \%$ \\
\hline
\end{tabular}

Berdasarkan Tabel 1 di atas dapat dijelaskan, bahwa frekuensi Satpam yang mempunyai durasi kerja selama 1-8 jam sebanyak 187 orang atau sebesar 100\%. Jadi dapat disimpulkan, bahwa seluruh Satpam mempunyai durasi kerja selama 1-8 jam dalam sehari, akan tetapi untuk pelaksanaannya dibagi menjadi 3 shift dalam sehari. Untuk pelaksanaan waktu pada shift kerja Satpam, dimulai dengan shift pagi berkisar antara jam 06.30-14.30, shift siang yang berkisar antara jam 14.30 - 22.30, dan shift malam yang berkisar antara $22.30-06.30$.

\section{Gaji atau Honorarium Satpam}

Gaji atau honorarium Satpam yang mempunyai status pekerjaannya Pegawai Negeri Sipil (PNS) didasari oleh pangkat golongan yang dimiliki oleh Satpam tersebut dan sudah diatur oleh pemerintah. Sedangkan Satpam yang berstatus pekerjaannya Pegawai Tidak Tetap (PTT) gaji atau honorarium yang diperoleh berdasarkan ketentuan atau kebijakan dari universitas masing-masing.

Tabel 2 Gaji atau Honorarium Satpam Per Bulan

\begin{tabular}{cccc}
\hline Kategori & Frekuensi & Persentase & Status Pekerjaan \\
\hline$<1,5$ juta & 1 & $0,53 \%$ & PTT \\
1,5 juta -2 juta & 86 & $45,99 \%$ & PTT \\
2 juta $-2,5$ juta & 70 & $37,43 \%$ & PTT \\
2,5 juta -3 juta & 5 & $2,67 \%$ & PNS I/c, I/d, II/a \\
3 juta $-3,5$ juta & 25 & $13,37 \%$ & PNS II/a, II/b, II/c, II/d \\
$>3,5$ juta & 0 & $0 \%$ & - \\
\hline Jumlah & 187 & $100 \%$ & \\
\hline
\end{tabular}

Berdasarkan Tabel 2 di atas dapat dijelaskan, bahwa Satpam yang memperoleh gaji $<1,5$ juta per bulan sebanyak 1 orang atau $0,53 \%$ dengan status pekerjaan sebagai PTT. Kemudian Satpam yang memperoleh gaji 1,5 juta - 2 juta sebanyak 86 orang atau $45,99 \%$ dengan status pekerjaan sebagai PTT. Kemudian Satpam yang memperoleh gaji 2 juta - 2,5 juta sebanyak 70 orang atau 37,43\% dengan status pekerjaan sebagai PTT. Satpam yang memperoleh gaji 2,5 juta - 3 juta sebanyak 5 orang atau 2,67\% dengan status pekerjaan sebagai PNS I/c, I/d, dan II/a. Kemudian Satpam yang memperoleh gaji 3 juta $-3,5$ juta sebanyak 25 orang atau 13,37\% dengan status pekerjaan sebagai PNS II/a, II/b, II/c, dan II/d. Jadi dapat disimpulkan, bahwa besar gaji yang paling tinggi yang diperoleh Satpam per bulan adalah 1,5 juta -2 juta dengan frekuensi 86 orang atau $45,99 \%$. 
Berdasarkan keterangan di atas dapat diketahui, bahwa terdapat 5 kategori gaji Satpam universitas negeri di Kota Malang per bulan dengan status pekerjaannya. Diurutkan mulai dari yang tertinggi ke yang terendah, yaitu Satpam dengan gaji 1,5 juta -2 juta per bulan, 2 juta $-2,5$ juta per bulan, 3 juta $-3,5$ juta per bulan, 2,5 juta -3 juta per bulan, dan Satpam dengan gaji $<1,5$ juta per bulan. Jadi dapat disimpulkan, bahwa pada universitas negeri di Kota Malang gaji yang paling banyak diperoleh oleh Satpam yaitu sebanyak 1,5 juta -2 juta per bulan yang mempunyai status pekerjaan sebagai PTT dengan jumlah 86 orang atau $45,99 \%$.

\section{Jenis-jenis Tugas Satpam}

Tugas pokok dan fungsi Satpam atau lebih dikenal dengan tupoksi Satpam, yaitu menyelenggarakan keamanan dan ketertiban di lingkungan tempat kerjanya yang meliputi aspek pengamanan fisik, personel, informasi, dan pengamanan teknis lainnya. Sedangkan fungsi Satpam, melindungi dan mengayomi lingkungan tempat kerjanya dari setiap gangguan keamanan, serta menegakkan peraturan dan tata tertib yang berlaku dilingkungan kerjanya. Seluruh Satpam melaksanakan tugas pokok dan fungsi Satpam tersebut.

Tupoksi Satpam tersebut terdapat beberapa tugas yang dilakukan Satpam rutin setiap harinya. Setiap jenis tugas memiliki intensitas yang berbeda. Setelah melakukan penelitian, peneliti menemukan sebanyak 19 jenis tugas Satpam universitas negeri di Kota Malang. Jenis tugas Satpam secara rinci dapat dilihat pada Tabel 3.

Tabel 3 Jenis-jenis Tugas Satpam

\begin{tabular}{|c|c|c|c|}
\hline No & Jenis-jenis Tugas Satpam & Jumlah & Persentase \\
\hline 1 & Pengaturan lalu lintas di wilayah kampus & 42 & $19,72 \%$ \\
\hline 2 & Melakukan patroli di sekitar kampus & 32 & $15,02 \%$ \\
\hline 3 & Berjaga di gerbang masuk/keluar kampus & 32 & $15,02 \%$ \\
\hline 4 & Menjaga parkir sepeda motor di fakultas & 37 & $17,37 \%$ \\
\hline 5 & Berjaga atau pelayanan tamu di gedung rektorat & 13 & $6,10 \%$ \\
\hline 6 & $\begin{array}{l}\text { Penertiban ojek online yang berada di dalam area } \\
\text { kampus }\end{array}$ & 4 & $1,885 \%$ \\
\hline 7 & Berjaga atau pelayanan tamu di gedung fakultas & 8 & $3,76 \%$ \\
\hline 8 & Berjaga di pos satpam & 4 & $1,88 \%$ \\
\hline 9 & Pelayanan dispensasi STNK & 1 & $0,47 \%$ \\
\hline 10 & $\begin{array}{l}\text { Penertiban pedagang kaki lima yang berjualan di } \\
\text { area kampus }\end{array}$ & 4 & $1,88 \%$ \\
\hline 11 & Penertiban jam malam di area kampus & 5 & $2,35 \%$ \\
\hline 12 & Pengamanan pada saat wisuda & 5 & $2,35 \%$ \\
\hline 13 & $\begin{array}{l}\text { Mengecek STNK pada kendaraan yang keluar kam- } \\
\text { pus }\end{array}$ & 18 & $8,45 \%$ \\
\hline 14 & Pengamanan temu wali mahasiswa & 2 & $0,94 \%$ \\
\hline 15 & $\begin{array}{l}\text { Pengamanan tamu penting yang berkunjung ke } \\
\text { kampus }\end{array}$ & 2 & $0,94 \%$ \\
\hline 16 & Berjaga di gedung sport center & 1 & $0,47 \%$ \\
\hline 17 & Pengawalan pengambilan uang di bank & 1 & $0,47 \%$ \\
\hline 18 & Pelayanan kunci ruangan laboratorium & 1 & $0,47 \%$ \\
\hline 19 & Pengecekan ruangan laboratorium & 1 & $0,47 \%$ \\
\hline
\end{tabular}


Berdasarkan Tabel 3 dijelaskan beberapa tugas Satpam universitas negeri di Kota Malang yang merupakan jabaran dari tugas pokok dan fungsi atau tupoksi Satpam. Dari tabel 3 di atas dapat dijelaskan, bahwa tugas Satpam yang mengatur lalu lintas di wilayah kampus sebanyak 42 orang atau 19,72\%, Satpam yang bertugas melakukan patroli di wilayah sekitar kampus sebanyak 32 orang atau 15,02\%, Satpam yang bertugas berjaga di gerbang masuk/keluar kampus sebanyak 32 orang atau 15,02\%, Satpam yang bertugas menjaga parkir sepeda motor di fakultas sebanyak 37 orang atau 17,37\%, Satpam yang bertugas berjaga dan pelayanan tamu di gedung rektorat sebanyak 13 orang atau $6,10 \%$.

Berdasarkan keterangan di atas dapat diketahui, bahwa terdapat 19 jenis-jenis tugas yang dikerjakan oleh Satpam universitas negeri di Kota Malang. Dari 19 jenis-jenis tugas tersebut terdapat 6 teratas jenis-jenis tugas yang dikerjakan oleh Satpam universitas negeri di Kota Malang, yaitu Pengaturan lalu lintas di wilayah kampus, menjaga parkir sepeda motor di fakultas, melakukan patroli di sekitar kampus, berjaga di gerbang masuk/keluar kampus, mengecek STNK pada kendaraan yang keluar kampus, dan berjaga atau pelayanan tamu di gedung rektorat. Jadi dapat disimpulkan, bahwa tugas yang paling banyak dikerjakan oleh Satpam universitas negeri di Kota Malang, yaitu pengaturan lalu lintas di wilayah kampus dengan jumlah 42 orang atau 19,72\%.

\section{Kriteria Pengembangan Karir Satpam}

Perkembangan karir Satpam ditentukan oleh pegawai Satpam itu sendiri. Satpam dapat mengetahui potensi yang dimiliki mereka untuk memperbaiki atau meningkatkan karir. Satpam memiliki kriteria pengembangan karir yang tersebar dalam 16 pernyataan.

Tabel 4 Kriteria Pengembangan Karir Satpam

\begin{tabular}{clcc}
\hline No & \multicolumn{1}{c}{ Kriteria Pengembangan } & Skor & Persentase \\
\hline 1 & Penilaian dan Evaluasi & 656 & $24,59 \%$ \\
2 & Prestasi Kerja & 474 & $17,77 \%$ \\
3 & Latar Belakang Pendidikan & 452 & $16,96 \%$ \\
4 & Pelatihan & 618 & $23,18 \%$ \\
5 & Kesetiaan/Pengabdian & 466 & $17,50 \%$ \\
& Jumlah & 2665 & $100 \%$ \\
\hline
\end{tabular}

Berdasarkan Tabel 4 di atas dapat disimpulkan, bahwa kriteria pengembangan karir Satpam tentang penilaian dan evaluasi mempunyai skor 656 atau 24,59\%, pada kriteria pengembangan karir Satpam tentang prestasi kerja mempunyai skor 474 atau $17,77 \%$, pada kriteria pengembangan karir Satpam tentang latar belakang pendidikan mempunyai skor 452 atau 16,96\%, pada kriteria pengembangan karir Satpam tentang pelatihan mempunyai skor 618 atau 23,18\%, dan pada kriteria pengembangan karir Satpam tentang kesetiaan atau pengabdian mempunyai skor 466 atau $17,50 \%$.

Kriteria pengembangan karir di atas dapat diketahui, bahwa kriteria pengembangan karir Satpam universitas negeri di Kota Malang terdiri dari 5 indikator kriteria pengembangan karir. Diurutkan dari yang tertinggi ke yang terendah kriteria pengembangan karir Satpam yaitu penilaian dan evaluasi, pelatihan, prestasi kerja, kesetiaan atau pengabdian, serta latar belakang pendidikan. Jadi dapat disimpulkan bahwa kriteria pengembangan karir Satpam universitas negeri di Kota Malang yaitu indikator penilaian dan evaluasi terhadap Satpam itu sendiri dengan skor 656 atau 24,59\%.

Selanjutnya perlu adanya pengklasifikasian untuk mengambil kesimpulan dari kriteria pengembangan karir Satpam. Pengklasifikasian kriteria pengembangan karir Satpam dibagi menjadi 3 kriteria, yaitu tinggi, sedang, dan rendah. Sebelumnya diketahui total skor tertinggi sebesar 935 dan total skor terendah sebesar 187. Jadi dapat diketahui kelas interval sebesar 249. 
Tabel 5 Hasil Klasifikasi Kriteria Pengembangan Karir Satpam

\begin{tabular}{clccc}
\hline No & Kriteria Pengembangan & Skor & Persentase & Kategori \\
\hline 1 & Penilaian dan Evaluasi & 656 & $24,59 \%$ & Sedang \\
2 & Pelatihan & 618 & $23,18 \%$ & Sedang \\
3 & Prestasi Kerja & 474 & $17,77 \%$ & Sedang \\
4 & Kesetiaan/Pengabdian & 466 & $17,50 \%$ & Sedang \\
5 & Latar Belakang Pendidikan & 452 & $16,96 \%$ & Sedang
\end{tabular}

Berdasarkan Tabel 5 di atas dapat disimpulkan, bahwa dari kelima kriteria pengembangan karir Satpam, yaitu penilaian dan evaluasi, prestasi kerja, latar belakang pendidikan, pelatihan, dan kesetiaan atau pengabdian mempunyai kriteria sedang yang mempunyai skor berkisar antara 437-686. Jadi dapat disimpulkan, bahwa kriteria pengembangan karir Satpam universitas negeri di Kota Malang yang paling tinggi yaitu kriteria pengembangan karir dengan indikator penilaian dan evaluasi yang diklasifikasikan dengan kategori sedang.

\section{Karir Jabatan yang Pernah Diduduki Satpam}

Satpam mempunyai kesempatan untuk memperbaiki atau meningkatkan karir mereka sendiri. Karir termasuk jabatan yang pernah atau yang telah diduduki Satpam universitas negeri di Kota Malang.

Tabel 6 Jabatan yang Pernah Diduduki Satpam

\begin{tabular}{clcc}
\hline No & \multicolumn{1}{c}{ Jabatan } & Jumlah & Persentase \\
\hline 1 & Anggota Satpam & 120 & $71,86 \%$ \\
2 & panitia penyelenggara acara kampus & 4 & $2,40 \%$ \\
3 & Komandan/ketua regu & 16 & $9,58 \%$ \\
4 & Petugas/tenaga kebersihan & 19 & $11,38 \%$ \\
5 & Staf Satpam & 2 & $1,20 \%$ \\
6 & Staf Administrasi & 4 & $2,40 \%$ \\
7 & wakil komandan satpam & 1 & $0,60 \%$ \\
8 & Sekretaris Satpam & 1 & $0,60 \%$
\end{tabular}

Berdasarkan Tabel 6 di atas dapat dijelaskan, bahwa Satpam yang menduduki jabatan sebagai anggota Satpam sebanyak 120 orang atau $71,86 \%$, Satpam yang pernah menduduki jabatan sebagai panitia penyelenggara acara kampus sebanyak 4 orang atau 2,40\%, Satpam yang pernah menduduki jabatan sebagai komandan/ketua regu sebanyak 16 orang atau 9,58\%, Satpam yang pernah menduduki jabatan sebagai petugas/tenaga kebersihan sebanyak 19 orang atau 11,38\%, Satpam yang pernah menduduki jabatan sebagai staf Satpam sebanyak 2 orang atau 1,20\%, Satpam yang pernah menduduki jabatan sebagai staf administrasi sebanyak 4 orang atau 2,40\%, Satpam yang pernah menduduki jabatan sebagai wakil komandan Satpam sebanyak 1 orang atau 0,60\%, dan Satpam yang pernah menduduki jabatan sebagai sekretaris Satpam sebanyak 1 orang atau $0,60 \%$.

Jabatan yang pernah diduduki oleh Satpam di atas dapat diketahui, bahwa jabatan yang pernah diduduki oleh Satpam ada 8 jenis jabatan, yaitu (1) Anggota Satpam; (2) Panitia penyelenggara acara kampus; (3) Komandan/ketua regu; (4) Petugas/tenaga kebersihan; (5) Staf Satpam; (6) Staf administrasi; (7) Wakil komandan Satpam; (8) Sekretaris Satpam. Jadi dapat disimpulkan, bahwa dari 8 jabatan yang pernah diduduki oleh Satpam universitas negeri di Kota Malang karir jabatan tertinggi yang pernah diduduki oleh Satpam universitas negeri di Kota Malang yaitu sebagai wakil komandan Satpam.

\section{PEMBAHASAN}

\section{Durasi Kerja Satpam}

Durasi kerja setiap pegawai telah ditentukan oleh pihak universitas dan telah dijelaskan kepada calon pegawai sebelum diterima kerja. Durasi kerja Satpam di setiap universitas seluruhnya sama, hanya saja jam kerja shiftnya yang berbeda. Sebagian besar Satpam bekerja dalam 8 jam setiap harinya. 
Pernyataan tersebut sesuai dengan Surat Keputusan Bersama Menteri Tenaga Kerja Republik Indonesia dan Kepala Kepolisian Republik Indonesia Nomor 275 dan 04 Tahun 1989 tentang Pengaturan Jam Kerja, Shift dan Jam Istirahat serta Pembinaan Tenaga Kerja Satpam, yaitu "memberlakukan aturan jam kerja dan istirahat bagi tenaga kerja Satpam di lingkungan perusahaan maupun badan hukum lainnya, menjadi 3 shift di mana setiap shift bertugas 8 jam sehari".

Universitas negeri di Kota Malang memberlakukan 8 jam kerja per hari kepada Satpam dengan 3 shift kerja per harinya, serta 5 hari bekerja dalam seminggu. Satpam universitas negeri di Kota Malang memulai kerja pada shift 1 atau pagi berkisar antara jam 06.30-14.30, shift 2 atau siang yang berkisar antara jam 14.30 - 22.30, dan shift 3 atau malam yang berkisar antara 22.30 - 06.30. Jadi di universitas negeri di Kota Malang durasi kerja atau jam kerja Satpam sudah sesuai dengan peraturan pemerintah, yaitu 8 jam kerja. Akan tetapi berbeda dalam pelaksanaan jam kerjanya.

Berdasarkan hasil penelitian, durasi atau jam kerja Satpam universitas negeri di Kota Malang yaitu 8 jam kerja. Hal tersebut sesuai dengan pendapat yang terdapat pada kajian teori, yaitu berdasarkan Surat Keputusan Bersama Menteri Tenaga Kerja Republik Indonesia dan Kepala Kepolisian Republik Indonesia Nomor 275 dan 04 Tahun 1989 tentang Pengaturan Jam Kerja, Shift dan Jam Istirahat serta Pembinaan Tenaga Kerja Satpam. Jadi durasi atau jam kerja Satpam universitas negeri di Kota Malang sesuai dengan kajian teori atau peraturan yang berlaku yaitu 8 jam kerja.

\section{Gaji atau Honorarium Satpam}

Gaji atau honorarium Satpam yang berstatus PNS sudah diatur oleh pemerintah dan didasari pada pangkat golongan yang dimiliki oleh Satpam tersebut. Sedangkan Satpam yang berstatus PTT gaji atau honorarium yang diperoleh berdasarkan kebijakan atau ketentuan dari universitas masing-masing. Besar gaji atau honorarium yang diterima oleh Satpam universitas negeri di Kota Malang Rp 1,5 juta - Rp 2 juta. Pemberian gaji atau honorarium kepada Satpam diberikan setiap bulannya. Pernyataan tersebut sesuai dengan pendapat Wibowo (2013: 352), upah menurut waktu adalah "suatu sistem penentuan upah yang dibayar menurut jangka waktu yang terpakai dalam menyelesaikan suatu pekerjaan, misalnya per jam, per hari, per minggu, per bulan, dan lain-lain".

Berdasarkan hasil penelitian, besar gaji atau honorarium yang diterima oleh Satpam universitas negeri di Kota Malang Rp 1,5 juta - Rp 2 juta. Dengan jumlah gaji tersebut sudah termasuk gaji pokok dan tunjangan. Pemberian gaji atau honorarium kepada Satpam diberikan setiap bulannya. Hal tersebut sesuai dengan pendapat yang terdapat pada kajian teori, yaitu menurut Wibowo dan berdasarkan Undangundang Republik Indonesia Nomor 13 Tahun 2003 tentang Ketenagakerjaan Pasal 94.

\section{Jenis-jenis Tugas Satpam}

Satpam mempunyai tugas dan fungsi yang harus dilaksanakan sebagai bentuk tanggungjawabnya kepada universitas. Setiap Satpam mempunyai tugas dan fungsi masing-masing. Terdapat 19 jenisjenis tugas yang dikerjakan oleh Satpam, di antaranya adalah pengaturan lalu lintas di wilayah kampus, melakukan patroli di sekitar kampus, berjaga di gerbang masuk/keluar kampus, menjaga parkir sepeda motor di fakultas, berjaga atau pelayanan tamu di gedung rektorat, penertiban ojek online yang berada di dalam area kampus, berjaga atau pelayanan tamu di gedung fakultas, berjaga di pos Satpam, pelayanan dispensasi Surat Tanda Nomor Kendaraan (STNK), penertiban pedagang kaki lima yang berjualan di area kampus, penertiban jam malam di area kampus, pengamanan pada saat wisuda, mengecek STNK pada kendaraan yang keluar kampus, pengamanan temu wali mahasiswa, pengamanan tamu penting yang berkunjung ke kampus, berjaga di gedung sport center, pengawalan pengambilan uang di bank, pelayanan kunci ruangan laboratorium, dan pengecekan ruangan laboratorium.

Pernyataan di atas sesuai dengan Peraturan Kepala Kepolisian Negara Republik Indonesia Nomor 24 Tahun 2007 Tentang Sistem Manajemen Pengamanan Organisasi, Perusahaan dan atau Instansi atau Lembaga Pemerintah, tugas pokok dan fungsi Satpam, yaitu "menyelenggarakan keamanan dan ketertiban di lingkungan tempat kerjanya yang meliputi aspek pengamanan fisik, personel, informasi, 
dan pengamanan teknis lainnya". Berdasarkan pernyataan di atas dapat diambil kesimpulan, bahwa masih ada 2 jenis tugas Satpam di universitas negeri di Kota Malang yang tidak sesuai dengan peraturan yang dicanangkan oleh pemerintah, yaitu pelayanan kunci ruangan laboratorium dan pengecekan ruangan laboratorium. Seharusnya tugas tersebut akan lebih efektif dan efisien diberikan kepada staf atau tenaga kependidikan yang bertugas di laboratorium tersebut.

\section{Kriteria Pengembangan Karir Satpam}

Perkembangan karir Satpam sebagian besar ditentukan oleh pegawai itu sendiri, Satpam dapat mengetahui potensi yang dimiliki oleh dirinya sendiri untuk memperbaiki atau meningkatkan karir mereka sendiri. Satpam memilih kriteria pengembangan karir yang tersebar dalam 16 pernyataan. Urutan kriteria pengembangan karir Satpam, yaitu penilaian dan evaluasi, pelatihan, prestasi kerja, kesetiaan atau pengabdian, dan latar belakang pendidikan. Pernyataan di atas sesuai dengan yang dikemukakan oleh Wahyudi (2002: 162) mengemukakan, bahwa indikator-indikator dalam pelaksanaan pengembangan karir ialah "penilaian dan evaluasi, prestasi kerja, latar belakang pendidikan, pelatihan yang telah diikuti, dan kesetiaan pada organisasi atau perusahaan".

Berdasarkan pernyataan di atas dapat diambil kesimpulan, bahwa kriteria pertama dari pengembangan karir Satpam, yaitu penilaian dan evaluasi dari pimpinan tentang kinerja yang telah dilaksanakan, pelatihan yang telah diikuti baik dari universitas maupun dari luar universitas, prestasi kerja yang dicapai Satpam selama melaksanakan tugas, kesetiaan atau pengabdian pada universitas, dan latar belakang pendidikan dengan kenaikan pangkat berdasarkan pendidikan yang dimiliki. Kriteria pengembangan karir Satpam di universitas negeri Kota Malang yang mempunyai skor tertinggi atau terbanyak yaitu kriteria pengembangan karir Satpam pada indikator penilaian dan evaluasi. Jadi kriteria pengembangan karir Satpam di universitas negeri Kota Malang lebih memperhatikan indikator penilaian dan evaluasi pada Satpam itu sendiri. Misalkan seperti penilaian kinerja Satpam dalam melaksanakan tugas setiap harinya, yang penilaian tersebut melibatkan pihak-pihak dari universitas tersebut.

\section{Jabatan yang Pernah Diduduki Satpam}

Beberapa jabatan yang pernah diduduki oleh Satpam di antaranya adalah anggota Satpam, panitia penyelenggara acara kampus, komandan atau ketua regu, petugas atau tenaga kebersihan, staf Satpam, staf administrasi, wakil komandan Satpam, sekretaris Satpam. Pernyataan tersebut sesuai dengan yang dikemukakan oleh Ardana dkk (2014: 121) perkembangan karir manusia dapat dibagi menjadi 5 (lima) fase, yaitu "Fase pengembangan (Growth), Fase eksplorasi (Exploration), Fase pemantaban (Establishment), Fase pembinaan (Maintenance), Fase kemunduran (Decline) masa sesudah pensiun atau melepaskan jabatan tertentu. Dalam fase ini orang membebaskan diri dari dunia kerja formal".

Berdasarkan pernyataan di atas dapat diambil kesimpulan, bahwa karir jabatan tertinggi yang dimiliki oleh Satpam universitas negeri di Kota Malang adalah menjadi seorang wakil komandan Satpam. Satpam mempunyai kesempatan untuk memperbaiki dan meningkatkan karir mereka sendiri. Tetapi perlu pertimbangan khusus untuk meninggalkan jabatan sebelumnya untuk memperbaiki karir mereka. Rentang usia Satpam berkisar antara 25-44 tahun, pada fase ini seseorang sudah memilih karir tertentu dan mendapatkan berbagai pengalaman positif maupun negatif dari pekerjaannya.

\section{KESIMPULAN DAN SARAN}

\section{Kesimpulan}

Berdasarkan hasil penelitian dan pembahasan temuan hasil penelitian dapat diperoleh kesimpulan bahwa: (1) Durasi kerja Satpam di setiap universitas seluruhnya sama, hanya saja pergantian jam 
shiftnya yang berbeda. Sebagian besar Satpam bekerja dalam 8 jam setiap harinya. Durasi kerja Satpam adalah dibagi menjadi 3 shift per hari secara bergiliran dan setiap shift bertugas 8 jam, serta dengan jumlah jam kerja akumulatif 40 jam dalam 1 minggu; (2) Gaji atau honorarium Satpam yang berstatus PNS didasari oleh pangkat golongan yang dimilikinya dan sudah diatur oleh pemerintah dalam undangundang. Sedangkan Satpam yang berstatus PTT gaji atau honorarium yang diperoleh berdasarkan ketentuan atau kebijakan dari universitas masing-masing, perolehan gaji yang diperoleh Satpam pada umumnya adalah 1,5 juta sampai dengan 2 juta per bulan dengan frekuensi 86 orang atau 45,99\%; (3) Terdapat 19 jenis tugas yang dikerjakan oleh Satpam, Sedangkan ada 2 jenis tugas Satpam yang tidak sesuai dengan peraturan pemerintah yaitu pelayanan kunci ruangan laboratorium dan pengecekan ruangan laboratorium; (4) Terdapat 5 pengembangan karir Satpam, urutan kriteria pengembangan karir Satpam dari yang tertinggi sampai yang terendah adalah penilaian dan evaluasi, pelatihan, prestasi kerja, kesetiaan atau pengabdian, dan latar belakang pendidikan; (5) Terdapat 8 karir jabatan yang pernah diduduki oleh Satpam, sedangkan karir jabatan tertinggi yang dimiliki oleh Satpam, yaitu sebagai wakil komandan Satpam dengan jumlah 1 orang.

\section{Saran}

Berdasarkan kajian implikasi yang diperoleh di atas, berikut akan disajikan beberapa saran bagi pihakpihak yang terkait, antara lain: (1) Bagi Sub Bagian Rumah Tangga universitas negeri di Kota Malang. Pertama, sebaiknya memperhatikan karir Satpam dengan membuat kebijakan terhadap penetapan gaji atau honorarium dan jam kerja Satpam yang berstatus PTT. Kedua, sebaiknya mendata seluruh Satpam yang masih berstatus PTT untuk dipertimbangkan kenaikan status pekerjaannya sebagai PNS. Ketiga, mengadakan pelatihan untuk Satpam agar Satpam dapat menambah kemampuan dan keterampilan yang telah dimilikinya; (2) Bagi Kepala Bagian Keamanan Universitas Negeri di Kota Malang. Pertama, lebih sering mengadakan penilaian dan evaluasi terhadap Satpam dalam melaksanakan tugas-tugasnya. Kedua, sebaiknya mengusulkan kenaikan pangkat atau status pekerjaan kepada pihak universitas bagi Satpam yang mempunyai prestasi kerja dan pengabdian yang tinggi kepada universitas. Ketiga, sebaiknya dapat membangkitkan rasa percaya diri Satpam dengan memberikan motivasi dan mengikutsertakan Satpam pada pelatihan-pelatihan yang diadakan oleh pihak universitas maupun di luar universitas; (3) Bagi Satpam. Pertama, sebaiknya dapat meningkatkan karir dengan melatih atau mengasah kemampuan lain yang dimiliki. Kedua, sebaiknya dapat merencanakan karir pekerjaan selanjutnya dengan baik. Ketiga, sebaiknya bekerja dengan sungguh-sungguh dengan melaksanakan tugas-tugas yang sudah menjadi tanggungjawabnya; (4) Bagi Dosen Jurusan Administrasi Pendidikan. Disarankan supaya melaksanakan pengabdian mengenai materi terkait manajemen sumber daya manusia khususnya pada karir Satpam maupun karir tenaga kependidikan lainnya. (5) Bagi peneliti lain. Penelitian ini hanya meneliti tentang karir Satpam. Hendaknya peneliti lain dapat mengembangkan penelitian yang lain, misalnya meneliti tentang analisis faktor-faktor perkembangan Satpam, analisis perjalanan karir Satpam, analisis jenjang karir pasca Satpam, dan lain sebagainya.

\section{DAFTAR RUJUKAN}

Ardana, I. K. Mujiati, W. N. \& Mudiartha, W. I. (2014). Manajemen Sumber Daya Manusia. Yogyakarta: Graha Ilmu.

Peraturan Kepala Kepolisian Negara Republik Indonesia Nomor 24 Tahun 2007 Tentang Sistem Manajemen Pengamanan Organisasi, Perusahaan dan atau Instansi atau Lembaga Pemerintah.

Siagian. S. P. (2006). Manajemen Sumber Daya Manusia. Jakarta: Bumi Aksara.

Sugiyono. (2011). Metode Penelitian Kuantitatif, Kualitatif, dan R \& D. Bandung: Alfabeta.

Surat Keputusan Bersama Menteri Tenaga Kerja Republik Indonesia dan Kepala Kepolisian Republik Indonesia Nomor 275 dan 04 Tahun 1989 tentang Pengaturan Jam Kerja, Shift dan Jam Istirahat serta Pembinaan Tenaga Kerja Satpam

Wahyudi, B. (2002). Manajemen Sumber Daya Manusia. Bandung: Sulita.

Wibowo. (2013). Manajemen Kinerja. Jakarta: PT. Raja Grafindo Persada. 